\title{
An exploration of learning styles used by social work students: a systematic review
}

\author{
Jose Frantz, Nicolette V. Roman and Mariana de Jager
}

\begin{abstract}
Social work educators are faced with the challenge of ensuring that students from diverse backgrounds are fully equipped with the necessary knowledge and skills. However, to be effective social work educators, the educator is required to understand the learning style of the student. The aim of this systematic review was to explore the learning styles of social work students for the purpose of understanding how to adapt and refine teaching strategies in social work. To this end, a search for descriptive studies in databases, which included Ebscohost (Academic Premier, CINAHL, SOcIndex, Psycharticles, Medline), DOAJ and Pubmed, was conducted. Eight articles met the criteria for inclusion in this systematic review. The target population included both undergraduate and postgraduate students. The studies were mainly conducted in developed countries. The results suggest that the most common approach for social workers is the diverging learning style, which entails having an interest in people, being aware of emotion, and a tendency to be imaginative. This review recommends that if there is an improved understanding of students' learning needs then educators could adapt their teaching strategies to accommodate and support students from diverse backgrounds, with diverse learning needs.
\end{abstract}

\section{Introduction}

According to the International Federation of Social Workers the global definition of social work is as follows:

Social work is a practice-based profession and an academic discipline that promotes social change and development, social cohesion, and the empowerment and liberation of people. Principles of social justice, human rights, collective responsibility and respect for diversities are central to social work. Underpinned by theories of social work, social sciences, humanities and indigenous knowledge, social work engages people and structures to address life challenges and enhance wellbeing (http://ifsw.org/policies/global-standards/).

The social work student, therefore, needs to be educated and skilled to accommodate for the diversity in the profession. This diversity in the profession includes learning perspectives from social work, health, sociology and anthropology, while integrating the core discipline of social work, ethical frameworks and fieldwork practice (Williams, Brown 
and Etherington 2012). If educators understand the diversity among students, they will have an improved chance of meeting the learning needs of the students capturing the interest and attention of students to ensure learning engagement (Felder 1996; Felder and Brent 2005). Napoli and Bonifas (2011) highlight that social work students may experience stress, exhaustion and trauma while studying in the field of social work, which may affect the way they learn. In addition to the complexity of studying in the field of social work, diverse students enter the profession of social work with different abilities and different ways in which they learn. Furthermore, departments of social work are challenged by changing health and social systems as they become complex thus placing additional demands on the social worker and demanding that students are equipped to deal with the changing environment. Cooper (2007) points out that the challenge for educators is to understand how these students learn and then adapt their teaching methods accordingly. Social work educators should, therefore, be able to adapt the education and training to graduate students that are able to meet the needs of society as social work practitioners ready for the ${ }_{21} \mathrm{st}$ century challenges. One aspect of improving student learning and developing the $21^{\mathrm{st}}$ century graduate is for the educator to have an understanding of student learning styles. Understanding the learning styles of students is important as it focuses on how students gain knowledge, how they think, how they value and judge, and how they act.

Learning styles are described as the learner's preferred pattern when trying to take in, process, and assimilate knowledge and information (Cassidy 2004; Munson 1993); a set of personal characteristics, which can be matched effectively to identical instruction methods (Brown 1998; Dunn and Dunn 1993). Understanding learning styles may not necessarily be a direct relationship between learning and teaching styles, but Williams et al. (2012) believe that they facilitate student learning and experiences as well as providing students with an understanding of how they learn best. Alternatively, Williams et al. (2012, 973) also indicate that a "lack of awareness of individual learning styles may result in communication problems, lack of student engagement and learning blocks in the classroom". Similarly, if learning styles are not considered in teaching and learning, a "one fits all model" of teaching may be adopted, which could have implications for future human capital needs (Hattacharya and Ameri Bin Mohd Sarip @ Shariff 2014).

In the current study, a systematic review was chosen in order to explore and understand the learning styles of social work students. The purpose of conducting this study was to review previous research in order to extrapolate themes of similarities and differences which highlight how social work students process information based on the learning styles used which could then translate theory into practice. Educators become the facilitators rather than the depositors of knowledge and skills, guiding and assisting students in learning for themselves taking into account the range of learning styles and preferences of the learners and introduce through various strategies opportunities for learning. 


\section{Methodology}

Databases including Ebscohost (Academic Premier, CINAHL, SocIndex, Psycarticles, Medline), DOAJ and Pubmed, were searched for descriptive studies which considered the learning styles of social work students. There were three stages of article screening which the authors implemented independently. The articles which were retrieved were screened according to predetermined criteria at title, abstract, and full-text levels.

In stage 1, articles were retrieved from the identified databases by the first author of this article (JF), using terms such as "learning styles", "social work", "social work education", and "social work practice". Hand-searching reference lists and cited reference searches were also conducted by the authors (NR and MDJ). The process of searching and final inclusion is illustrated in Figure 1.

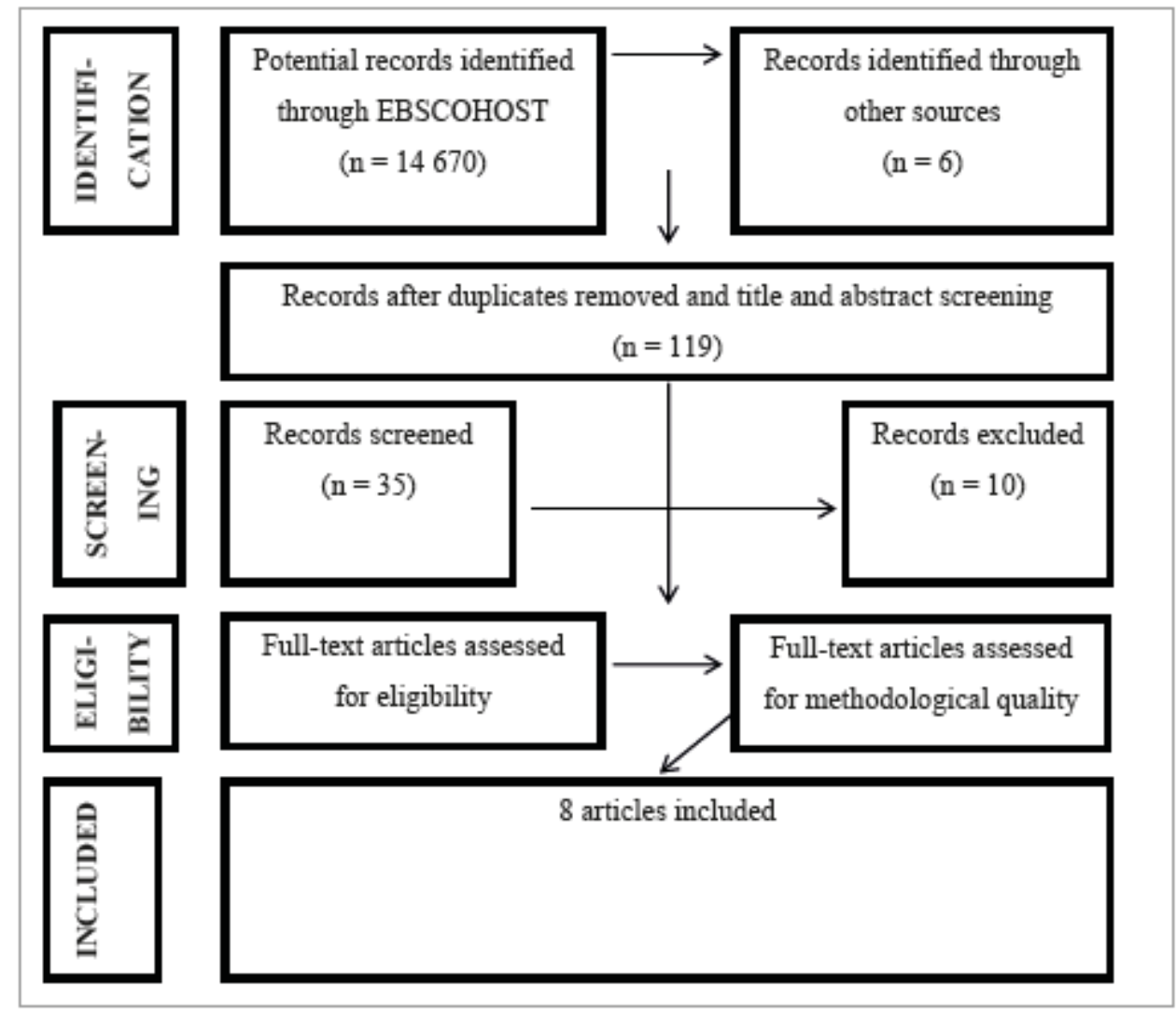

Figure 1: Process followed to screen articles for inclusion in the review

Articles were limited to those printed in English-language journals, and with a specific focus on the learning styles (I) of social work students (P) and their impact on clinical and classroom teaching (O). The reference lists of articles retrieved for inclusion in the review were hand-searched to identify other relevant articles. Once the filters were applied, the term "learning styles" yielded 14760 articles. Once "social work students" was added, the number dropped to 119 articles. The titles of 35 articles were reviewed and retrieved. 
During stage 2, the titles and abstracts of articles $(n=35)$ were reviewed to assess their eligibility based on the inclusion criteria, relevance, and removal of duplicates for inclusion in this review using the population, issue and outcome (PIO) was used as a guide to determine the first round of eligibility. Articles were identified as relevant to the review if they were descriptive studies aiming to identify the learning styles of dents and/or their supervisors. At this stage, the number of articles was reduced to 15 for consideration and full-text retrieval. Articles were excluded if the population were not social work students and focused on how supervisors interpreted student learning styles, rather than reporting on the students' learning styles.

During stage 3, all retrieved articles $(n=8)$ were independently assessed for methodological quality using the questions put forward by Frantz and Mthembu (2014) for relevance, and the removal of duplications. The methodological quality was assessed (see Table 1). Reviewer JF critically appraised the articles, using the identified critical appraisal tool and this was verified by the reviewers NR and MDJ. 
Table 1: Methodological quality appraisal tool

\begin{tabular}{|c|c|c|c|c|}
\hline 1 & \multicolumn{3}{|c|}{$\begin{array}{l}\text { Sampling method: Was it representative of the population intended to the } \\
\text { study? } \\
\text { A. Non-probability sampling (including: purposive, quota, convenience and } \\
\text { snowball sampling) } \\
\text { B. Probability sampling (including: simple random, systematic, stratified g, } \\
\text { cluster, two-stage and multi-stage sampling) }\end{array}$} & 1 \\
\hline 2 & \multicolumn{3}{|c|}{$\begin{array}{l}\text { Was a response rate mentioned within the study? (Respond no if } \\
\text { response rate is below } 60 \text { ) } \\
\text { A. No } \\
\text { B. Yes }\end{array}$} & \\
\hline 3 & \multicolumn{3}{|c|}{$\begin{array}{l}\text { Was the measurement tool used valid and reliable? } \\
\text { A. No } \\
\text { B. Yes }\end{array}$} & \\
\hline 4 & \multicolumn{3}{|c|}{$\begin{array}{l}\text { Was it a primary or secondary data source? } \\
\text { A. Primary data source } \\
\text { B. Secondary data source (survey, not designed for the purpose) }\end{array}$} & \\
\hline 5 & \multicolumn{3}{|c|}{$\begin{array}{l}\text { Were learning styles a variable in the study? } \\
\text { A. No } \\
\text { B. Yes }\end{array}$} & \\
\hline 6 & \multicolumn{3}{|c|}{$\begin{array}{l}\text { Was the relationship/association between learning styles and social work } \\
\text { students explored? } \\
\text { A. No } \\
\text { B. Yes }\end{array}$} & \\
\hline \multicolumn{5}{|c|}{ 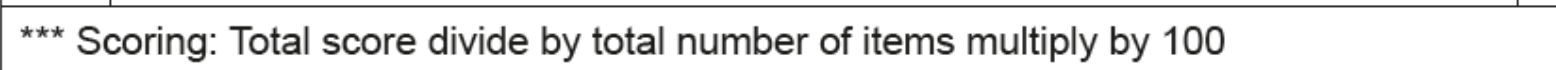 } \\
\hline \multicolumn{5}{|c|}{ Methodological Appraisal Score } \\
\hline \multicolumn{2}{|c|}{ Bad } & Satisfactory & \multicolumn{2}{|l|}{ Good } \\
\hline \multicolumn{2}{|c|}{$0-33 \%$} & $34-66 \%$ & \multicolumn{2}{|l|}{$67-100 \%$} \\
\hline
\end{tabular}

The findings of the methodological quality appraisal of the articles are given in Table 2. No articles were excluded because of poor methodological quality, as the contribution of the articles to knowledge of the learning styles used by social work students was found to be relevant. Data from all eight studies are presented in a narrative summary to make sense of the findings. The data extracted included the characteristics of participants, their learning styles and tools, and recommendations for teaching approaches. 
Table 2: Findings from the methodological quality appraisal

\begin{tabular}{|l|l|l|l|l|l|l|l|l|}
\hline Reference & Q1 & Q2 & Q3 & Q4 & Q5 & Q6 & Score & $\%$ \\
\hline Raschick, Maypole and Day (1998) & 0 & 1 & 1 & 1 & 1 & 1 & 5 & 83 \\
\hline Itzhaky and Eliahou (2001) & 0 & 0 & 1 & 1 & 1 & 1 & 4 & 66 \\
\hline Massey, Kim and Mitchell (2011) & 0 & 1 & 1 & 1 & 1 & 0 & 4 & 66 \\
\hline $\begin{array}{l}\text { Sabo, Shingles, Lopes, Toner, Naeve- } \\
\text { Velguth and Woods (2010) }\end{array}$ & 0 & 1 & 1 & 1 & 1 & 0 & 4 & 66 \\
\hline Williams et al. (2012) & 0 & 0 & 1 & 1 & 1 & 0 & 3 & 50 \\
\hline Wolfsfeld and Haj-Yahia (2010) & 0 & 1 & 1 & 1 & 1 & 1 & 5 & 83 \\
\hline Kruzich, Friesen, and Van Soest (1986) & 0 & 1 & 1 & 1 & 1 & 1 & 5 & 83 \\
\hline Cartney (2000) & 0 & 0 & 1 & 1 & 1 & 0 & 3 & 50 \\
\hline
\end{tabular}

\section{Results and discussion}

The aim of this review and synthesis of the literature was to describe the learning styles of social work students and their supervisors, and make recommendations for teaching and fieldwork practice.

\section{Characteristics of the studies included}

Of the eight studies included for review, seven involved undergraduate students as participants (Cartney 2000; Itzhaky and Eliahou. 2001; Kruzich et al. 1986; Massey et al. 2011; Sabo et al. 2010; Williams et al. 2012; Wolfsfeld and Haj-Yahia 2010) and two postgraduate students (Kruzich, et al., 1986; Raschick, et al., 1998). In addition, four of the studies also included supervisor learning styles (Cartney 2000; Kruzich et al. 1986; Raschick et al. 1998; Wolfsfeld and Haj-Yahia 2010). The studies were primarily carried out in developed areas such as London (Cartney 2000), the United States of America (Kruzich et al. 1986; Massey et al. 2011; Raschick et al. 1998; Sabo et al. 2010), Australia (Williams et al. 2012), and Israel (Itzhaky and Eliahou. 2001; Wolfsfeld and Haj-Yahia 2010). It was evident that there is a lack of literature focusing on understanding the learning patterns of students in resource-constrained or developing countries. This is important especially in but not limited to a country such as South Africa, where higher education institutions are faced with the reality of diversity but with the addition of limited resources.

\section{Learning styles and tools}

Learning styles were measured with tools such as the Kolb's Learning Style Inventory (Kruzich et al. 1986; Massey et al. 2011; Raschick et al. 1998; Williams et al. 2012; Wolfsfeld and Haj-Yahia 2010), the Supervisor Styles Inventory (Itzhaky and Eliahou 2001), the Honey and Mumford Learning Style questionnaire (Cartney 2000) and the VARK (visual, aural, read/write, kinaesthetic) questionnaire (Sabo et al. 2010). 


\section{VARK questionnaire}

The VARK questionnaire characterises learning styles in terms of students using their sensors to take in new information, which would include sight, hearing, touch, etc. In understanding the questionnaire, it is important to know that learners can use all four sensory modes, but that one tends to be more dominant. For example, visual learners learn through seeing pictures and learn well with PowerPoint presentations or video material or by reading study material themselves. The learning approach of auditory learners is to use their ears and auditory capacities (perception) when in lectures and in discussion groups such as when learning resources and ideas are discussed. The reading/ writing learners, kinaesthetic learners or tactile learners need to physically interact with the learning material. The emphasis for these learners are doing and experiencing (Sabo et al. 2010). In the study by Sabo et al. (2010), the VARK questionnaire indicated that health profession students (such as social work students) are multimodal, with the common modes being reading/writing and kinaesthetic. However, this study was difficult to generalise to social work students only, as it was a multidisciplinary undertaking and the data were analysed as a collective, not per discipline.

\section{Honey and Mumford questionnaire}

The study by Cartney (2000) uses the Honey and Mumford questionnaire to explore students' and supervisors' perceptions regarding the use of specific learning styles to promote student learning in a practical setting. According to the questionnaire developed by Honey and Mumford (1992), a student's "learning style" is a reflection of one preferred stage chosen from four stages in the adult learning cycle. These four stages are as follows: (1) the activist stage in which the learner experiences, (2) the reflector stage in which the learner reviews everything, (3) the theorist stage in which the learner draws conclusions based on the experience and the review process, and (4) the pragmatist stage in which the learner plans the next steps (Figure 2). 


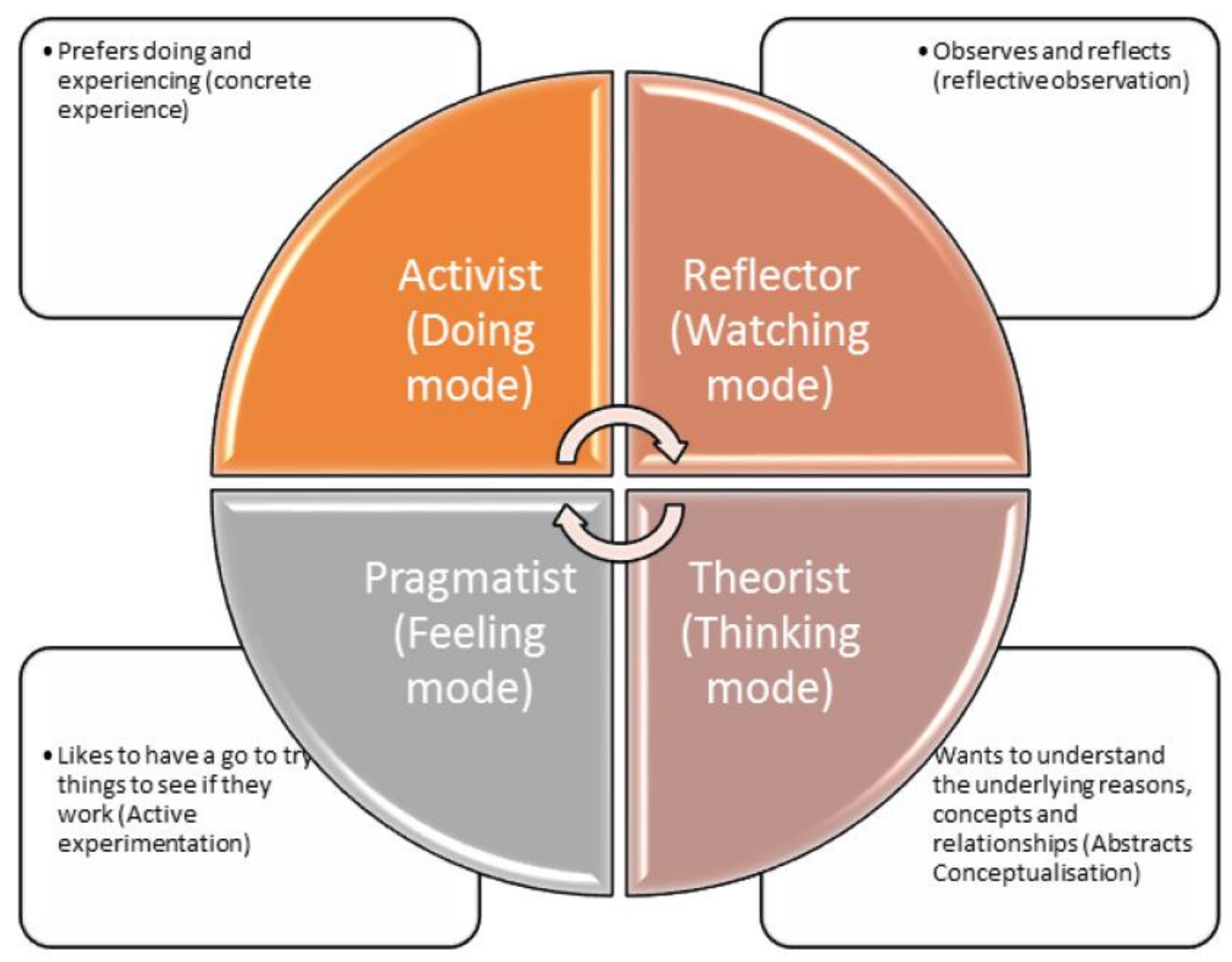

Figure 2: Honey and Mumford learning stages

Students generally employ components of all four stages, but they tend to have a preference for one - this should be considered when engaging them in complex activities. In the study by Cartney (2000) it was reported that although supervisors felt that understanding student learning styles was useful, they did not use this knowledge to assist students in a practical setting. The students participating in this study felt that it is important to know the impact of learning and teaching styles on their placement experiences.

They reported, however, that there were advantages and disadvantages to having similar learning styles. There tended to be differences in the learning styles used by the students and their supervisors, but the latter did not use the information flowing from the research to improve the learning experiences of their students. This is a concern, as reflective supervisors who continue to impose their style of learning on pragmatic students will cause problems. Reflective learners tend to want to stand back and ponder experiences from different perspectives, whereas pragmatic learners are keen to try out ideas in practice, rather than think about them (Goldstein and Bokoros 1992). However, it may be posited that if attention is not given to developing all four aspects of learning then this could possibly 
impact on the learning of the student and their development as practitioners. Cartney (2000) highlights that when training social work students we cannot only focus on reflection, but need to develop pragmatics as well so as to address the needs of society.

\section{Task versus people orientated tool}

The tool used by Itzhaky and Eliahou (2001) classified students as either task or people orientated. The latter learning style focuses on relationships and within these relationships is the growth and development of self-awareness, emotional development, professional competence and effectiveness of the student (Munson 1993). In the task- orientated learning style the focus is on tasks, roles, goals and structure for supervision and therapy. This learning style would include planning, organising, monitoring and evaluating activities, resources and improvement within the teaching and learning environment (Munson 1993). The task-orientated learning style, as identified by Munson (1993), therefore, will potentially encourage and promote the effectiveness and success of supervision and therapy for the client. This study highlighted the importance of determining where the student finds him/herself and then the opposite can be promoted and encouraged or developed.

\section{Kolb's Learning Style Inventory}

The most commonly used tool is the Kolb's Learning Style Inventory (KLSI) (Kolb and Kolb 2005), which classifies learning styles into four categories, namely divergers, accommodators, assimilators and convergers. In addition, there are four different learning modes, namely abstract conceptualisation (AC), active experimentation (AE), concrete experience (CE) and reflective observation (RO). The KLSI assesses the perception and processing styles of individuals (Kolb and Kolb 2005). Within this inventory, perception refers to the use of the senses in taking in information, either through concrete experience (CE) or abstract conceptualisation (AC). Processing, on the other hand, takes the information as either new or then assimilates the information with prior knowledge, either through reflective observation (RO) or active experimentation (AE). Table 3 provides a summary of what the different styles entail. 
Table 3: Description of Kolb's four learning styles

\begin{tabular}{|l|l|}
\hline Learning style & Definition \\
\hline Diverger (CE and RO) & $\begin{array}{l}\text { Divergers prefer to view a situation from a number of different } \\
\text { perspectives. Tend to use information from their senses and } \\
\text { feelings. }\end{array}$ \\
\hline Assimilator (AC and RO) & $\begin{array}{l}\text { Assimilators are competent at understanding a wide variety } \\
\text { of information and putting it into a concise logical order. } \\
\text { Characterised by abstract thinking and theory generation. }\end{array}$ \\
\hline Converger (AC and AE) & $\begin{array}{l}\text { Convergers like to apply practical ideas to problems and } \\
\text { perform at their best when there is only one answer to the } \\
\text { problem. }\end{array}$ \\
\hline Accommodator (CE and AE) & $\begin{array}{l}\text { Accommodators enjoy hands-on opportunities and } \\
\text { experience and thrive in new challenging situations. Tend to } \\
\text { people oriented and learn through trial and error problem- } \\
\text { solving. }\end{array}$ \\
\hline
\end{tabular}

Based on the studies that used the KLSI, the following results emerged for social work students and supervisors. The summary is presented in Table 4. Although the results presented in Table 4 show variations among the types of learning styles, the most common learning style is that of the diverger. This is supported by Kolb and Kolb (2005) who indicate that social workers have a diverging learning style because of being (1) interested in people, (2) resourceful, inspirational and imaginative, and (3) aware of emotions. Divergers function between watching and feeling when learning and are, therefore, able to use different perspectives and approaches when dealing with a concept or issue. The second largest learning style is the accommodator and this group tends to enjoy learning by concrete experience and active experimentation. The accommodative learners function between feeling and doing. These learners often adapt to change, focus on the goal, function within a structure, are organised, will monitor and find solutions for problems. It is important to realise that a mismatch between student learning styles and teaching methods of the educator can adversely affect academic performance (Felder and Henriques 1995). 
Table 4: Results in terms of learning styles according to KLSI

\begin{tabular}{|c|c|c|c|c|c|}
\hline Author & $\begin{array}{l}\text { Student/ } \\
\text { Supervisor }\end{array}$ & Diverger & Assimilator & Converger & Accommodator \\
\hline $\begin{array}{l}\text { Kruzich et } \\
\text { al. (1986) }\end{array}$ & $\begin{array}{l}\text { Student } \\
\text { (Undergraduates) } \\
\text { Student } \\
\text { (Postgraduates) } \\
\text { Supervisor } \\
\text { Academics }\end{array}$ & $\begin{array}{l}\text { Majority } \\
\text { Majority }\end{array}$ & & Majority & Majority \\
\hline $\begin{array}{l}\text { Raschick et } \\
\text { al. (1998) }\end{array}$ & $\begin{array}{l}\text { Student } \\
\text { (Postgraduates) } \\
\text { Supervisor }\end{array}$ & $\begin{array}{l}4 \% \\
10 \%\end{array}$ & $\begin{array}{l}18 \% \\
10 \%\end{array}$ & $\begin{array}{l}24 \% \\
23 \%\end{array}$ & $\begin{array}{l}38 \% \text { (Majority) } \\
48 \% \text { (Majority) }\end{array}$ \\
\hline $\begin{array}{l}\text { Wolfsfeld } \\
\text { and Haj- } \\
\text { Yahia } \\
(2010)\end{array}$ & $\begin{array}{l}\text { Student } \\
\text { (Undergraduates) } \\
\text { Supervisor }\end{array}$ & $\begin{array}{l}38.6 \% \\
\text { (Majority) } \\
78 \% \\
\text { (Majority) }\end{array}$ & $\begin{array}{l}22.3 \% \\
6.6 \%\end{array}$ & $\begin{array}{l}7.9 \% \\
0.0 \%\end{array}$ & $\begin{array}{l}31.2 \% \\
15.3 \%\end{array}$ \\
\hline $\begin{array}{l}\text { Massey et } \\
\text { al. (2011) }\end{array}$ & $\begin{array}{l}\text { Student } \\
\text { (Undergraduates) }\end{array}$ & $\begin{array}{l}46.5 \% \\
\text { (Majority) }\end{array}$ & $11.6 \%$ & $3.5 \%$ & $34.8 \%$ \\
\hline $\begin{array}{l}\text { Williams et } \\
\text { al. (2012) }\end{array}$ & $\begin{array}{l}\text { Student } \\
\text { (Undergraduates) }\end{array}$ & $15 \%$ & $29 \%$ & $\begin{array}{l}36 \% \\
\text { (Majority) }\end{array}$ & $20 \%$ \\
\hline
\end{tabular}

\section{Recommendations for teaching and learning}

According to Richmond and Cummings (2005), four learning environments can be linked to the four learning styles: (1) the symbolic learning environment and the convergent and assimilative learning styles, (2) the perceptual learning environment and the divergent and assimilative learning styles, (3) the behavioural learning environment and the convergent and accommodative learning styles, and (4) the affective learning environment and the divergent and accommodative learning styles. According to this review the affective environment is relevant to social work students because, in preparing to be novice practitioners, there is a requirement for affective learning so that students are able to learn about empathy or grief within the context of health professional education in order to improve their attitudes and beliefs (Schaber, Wilcox, Whiteside, Marsh and Brooks 2010).

Based on the reviews there is evidence that academics and supervisors involved in social work education need to understand students' learning styles, in order to make the learning process more interesting and effective. The authors would, however, caution that no single diagnostic instrument can solve all learning problems, though it can assist in guiding the learning process. According to Cartney (2000), the introduction of learning style questionnaires cannot be done in isolation, as academics and supervisors do not always understand how to use the information to improve the learning experience of their students. Given the shift in higher education to student-centred learning, educators need to adapt their teaching styles to accommodate the learning styles of students (Schaefer and Zygmont 2003). In addition to this shift, the increasingly complex role of social workers 
requires students to have critical thinking skills and thus educators need to consider new learning strategies that can facilitate these demands.

When focusing on divergent and assimilative learners, Massey et al. (2011) indicate that divergers perform better in situations that call for the generation of ideas, in which they learn by experience and have time for reflection. Social work educators and supervisors are challenged in terms of how to translate abstract knowledge and concrete skills to students, to build their knowledge and skills into competent practice. For knowledge to be transferred, learning must have occurred. If learning does not occur there may be a challenge in applying the knowledge elsewhere. According to Billing (2007), knowledge translation can only occur if the learning experience is facilitated appropriately.

Williams et al. (2012) suggest that in order to meet this challenge, by understanding the students' learning style and needs, educators can develop flexible student-centred curricula that provide opportunities for all types of learning styles to bridge the theory- practice gap. Itzhaky and Eliahou (2001) maintain that educators and supervisors need to show students empathy and contribute effectively to their growth. If educators understand this role and allow students the time and opportunity to generate their own ideas and understand them, they will be providing them with realistic or authentic learning opportunities. A concern raised by Wolfsfeld and Haj-Yahia (2010) is whether educators and supervisors are able to change from a natural style of learning to accommodate the needs of the student in both theory and practice. By learning to understand learning styles, educators can assist students in translating theoretical concepts they read about in textbooks into real, authentic experiences using different teaching strategies. Newton, Billett, Jolly and Okerby (2009, 324) indicate that "the influence of those who directly guide their [students] learning, albeit academic or clinical staff, is central to students' engagement”.

There are classroom strategies which could be used to implement the different learning styles within particular learning environments, which are indicated by Richmond and Cummings (2005). In a symbolic learning environment, teaching strategies could focus on computer-based or online teaching, online games, small group discussions, participatory teaching and learning and problem-based learning. For a behavioural learning environment, the online teaching strategies could be used but the strategies also include computer-based simulations, role play and observations. The perceptual learning environment could include the more traditional approaches of teaching such as face-to-face lectures, brainstorming, reflective activities, writing notes, and hands- on experiences in the classroom/practice. In an affective learning environment, the strategies accommodate the motivation of the student to learn. In order to do this, the strategies could acknowledge prior learning, ensure the information is relevant as stimulating and involve the learner throughout the teaching process. These would include reinforcing the desired outcomes, pairing, and face-to-face lectures with the main purpose of lowering anxiety. 


\section{Conclusion}

Although varying tools are used to evaluate learning styles, there are factors identified considering the relations between students' learning preferences and the teaching methods employed, especially their application in a clinical setting. There is limited evidence on the impact of understanding learning styles and how adjusting to the students' learning styles will affect specific outcomes such as academic performance. Further research is needed to strengthen the evidence base for understanding learning styles and their effect on changes in the educational teaching methods that educators use, with a specific focus on the South African context and the effect of the practice or fieldwork setting. In addition, social work educators and health professional educators need training in understanding how they can adapt their teaching methods to meet students' learning needs.

However, as social work teachers we need to aim to provide a viable teaching environment and thus if understanding student learning styles will assist, then educators should commit to adapting their teaching styles for difficult tasks and capitalise on students' preferred learning styles to ensure that knowledge and skills are reinforced. For tasks that are easier to perform, educators can adopt a flexible approach as most students can learn effectively provided a combination of approaches is used as teaching strategies. This will also assist in addressing the diversity in backgrounds and experiences of our students. Through a better understanding of students' learning styles, social work teachers can adapt their teaching and learning styles, practices and environments to accommodate and support students from diverse backgrounds with diverse learning needs and preferences. Educators should also maximise the learning opportunities for students in order to ensure that they are able to confidently apply their knowledge and skills gained. 


\section{References}

Billing, D. 2007. "Teaching for Transfer of Core/Key Skills in Higher Education: Cognitive Skills.” Higher Education 53 (4): 483-516. https://doi.org/10.1007/s10734-005-5628-5

Brown, B. L. 1998. "ERIC ED422478: Learning Styles and Vocational Education Practice." In Clearinghouse on Adult, Career and Vocational Education. Columbus: ERIC Publications.

Cartney, P. 2000. "Adult learning styles: Implications for Practice Teaching in Social Work." Social Work Education 19 (6): 609-626. https://doi.org/10.1080/02615470020002335

Cassidy, S. 2004. "Learning Styles: An Overview of Theories, Models, and Measures." Educational Psychology 24 (4): 419-444. https://doi.org/10.1080/0144341042000228834

Cooper, L. 2007. "Backing Australia's Future: Teaching and Learning in Social Work Education." Australian Social Work 60 (1): 94-106. https://doi.org/10.1080/03124070601166745

Dunn, R., and K. Dunn. 1993. Teaching Secondary Students through Their Individual Learning Styles: Practical Approaches for Grades 7-12. Boston: Allyn and Bacon.

Felder, R. M. 1996. "Matters of Style.” ASEE Prism 6 (4): 18-23.

Felder, R. M., and R. Brent. 2005. "Understanding Student Differences." Journal of Engineering Education 94 (1): 57-72. https://doi.org/10.1002/j.2168-9830.2005.tboo829.x

Felder, R. M., and E. R. Henriques. 1995. "Learning and Teaching Styles in Foreign and Second Language Education." Foreign Language Annals 28 (1): 21-31. https://doi.org/10.1111/j.1944-9720.1995. tboo767.x

Frantz, J., and S. Mthembu. 2014. "Learning Styles among Nursing Students: The Implications for Higher Education Institutions - A Systematic Review.” SAJHE 28 (6): 18141829.

Goldstein, B., and B. Bokoros. 1992. "Tilting at Windmills: Comparing the Learning Style Inventory and the Learning Style Questionnaire." Educational and Psychological Measurement 52 (3): 701-708. https://doi.org/10.1177/0013164492052003020

Hattacharya, E., and Ameri Bin Mohd Sarip @ Shariff. 2014. "Learning Style and Its Impact in Higher Education and Human Capital Needs." Procedia: Social and Behavioral Sciences 123: 485-494. https://doi.org/10.1016/j.sbspro.2014.01.1448

Honey, P., and A. Mumford. 1992. The Manual of Learning Styles. Maidenhead: Ardingley House. 
International Federation of Social Workers. 2012. http://ifsw.org/policies/global-standards/

Itzhaky, H., and A. Eliahou. 2001. "The Effect of Learning Styles and Empathy on Perceived Effectiveness of Social Work Student Supervision.” The Clinical Supervisor 20 (2): 19-29. https://doi.org/10.1300/ Joo1v20no2_02

Kolb, A., and D. Kolb. 2005. The Kolb Learning Style Inventory Version 3.1: 2005 Technical Specifications. Boston, MA: Hay Group, Hay Resources Direct.

Kruzich, J., B. Friesen, and D. van Soest. 1986. "Assessment of Student and Faculty Learning Styles." Research and Application Journal of Social Work Education 22 (3): 2230 .

Massey, M., S. Kim, and C. Mitchell. 2011. "A Study of the Learning Styles of Undergraduate Social Work Students.” Journal of Evidence-Based Social Work 8 (3): 294-303. https://doi.org/10.1080/1543371 4.2011.557977

Munson, C.F. 1993. Clinical Social Work Supervision. New York: Haworth Press.

Newton, J., S. Billett, B. Jolly, and C. Okerby. 2009. "Lost in Translation: Barriers to Learning in Health Professional Clinical Education." Learning in Health and Social Care 8 (4): 315-327. https://doi.org/10.1111/j.1473-6861.2009.00229.x

Napoli, M., and R. Bonifas. (2011). "From Theory toward Empathic Self-care: Creating a Mindful Classroom for Social Work Students." Social Work Education 30 (6): 635-649. https://doi.org/10.10 80/02615479.2011.586560

Raschick, M., D. Maypole, and P. Day. 1998. "Improving Field Education through Kolb's Learning Theory." Journal of Social Work Education 34 (1): 31-42.

Richmond, A. S., and R. Cummings. 2005. "Implementing Kolb's Learning Styles into Online Distance

Education." International Journal of Technology in Teaching and Learning 1 (1): 45-54.

Sabo, R., R. Shingles, J. Lopes, J. Toner, S. Naeve-Velguth, and S. Woods. 2010. "Using Online Instruments to Assess Learning Styles of Health Professional Students: A Pilot Study." The Internet Journal of Allied Health Sciences and Practice 10 (2): 1-8.

Schaber, P., K. Wilcox, A. L. Whiteside, L. Marsh, and D. C. Brooks. 2010. "Designing Learning Environments to Foster Affective Learning: Comparison of Classroom to Blended Learning." International Journal for the Scholarship of Teaching and Learning 4 (2): 1-18. https://doi. org/10.20429/ijsotl.2010.040212 
Schaefer, K. M., and D. Zygmont. 2003. "Analyzing the Teaching Style of Nursing Faculty: Does It Promote a Student-Centered or Teacher-Centered Learning Environment?” Nursing Education Perspectives 24 (5): 238-245.

Williams, B., T. Brown, and J. Etherington. 2012. "Learning Style Preferences of Undergraduate Social Work Students." Social Work Education: The International Journal 32 (8): 972-99o. http://dx.doi.or g/10.1080/02615479.2012.730142

Wolfsfeld, L. and M. Haj-Yahia. 2010. "Learning and supervisory Styles in the Training of Social Workers." The Clinical Supervisor 29 (1): 68-94. https://doi.org/10.1080/07325221003742066 